\title{
Seasonal changes in the concentration of anionic surfactants in estuarine sediments from the River Guadalete (Cadiz, Spain)
}

\author{
PABLO A. LARA-MARTÍN, CARMEN CORADA-FERNÁNDEZ, \\ ABELARDO GÓMEZ-PARRA and EDUARDO GONZÁLEZ-MAZO \\ Universidad de Cádiz, Facultad de Ciencias del Mar y Ambientales, Departamento de Química Física, \\ Avda. República Saharaui s/n 11510 Puerto Real, Cádiz, Spain. E-mail: pablo.lara@uca.es
}

\begin{abstract}
SUMMARY: The presence and longitudinal and temporal distributions of the two main anionic surfactants, linear alkylbenzene sulfonates (LAS) and alkyl ethoxysulfates (AES), were monitored in surface sediments from the Guadalete estuary, located in the north of the Bay of Cadiz (SW of Spain). Seasonal samplings were performed for two years at three different stations; one of them located up-stream near the discharge outlet of a wastewater treatment plant (WWTP). A control station was also sampled in a tidal channel within the boundaries of a natural park adjacent to the estuary. LAS and AES concentration values ranged from 196 to $2864 \mathrm{ng} \mathrm{g}^{-1}$ and from 147 to $557 \mathrm{ng} \mathrm{g}^{-1}$, respectively, the lowest values corresponding to the control station and the highest ones found near the WWTP outlet. A general decrease in the concentrations of both surfactants was found in summer, when degradation processes are faster, whereas the highest concentrations were detected during the wet months, when temperature decreases and rainwater exceeds the WWTP capacity, so untreated wastewater is discharged directly into the river. Due to differential sorption and degradation processes, the relative distribution of LAS homologues in sediments showed higher percentages for those having longer alkyl chains, whereas AES homologues with an even carbon unit number in the alkyl chain and AES ethoxymers with fewer ethylene groups were predominant. No hazard for aquatic organisms was foreseen at the concentrations found for both surfactants along the estuary.
\end{abstract}

Keywords: anionic surfactants, sediments, estuaries, seasonal variations, wastewater, environmental risk assessment.

RESUMEN: VARIACIONES ESTACIONALES DE TENSIOACTIVOS ANIÓNICOS EN SEDIMENTOS ESTUÁRICOS DEL Río GUADALETE (CÁDIZ, EsPAÑA). - Se ha realizado un seguimiento de la presencia y las distribuciones temporal y longitudinal de los dos tensioactivos aniónicos más usados -sulfonato de alquilbenceno lineal (LAS) y alquil etoxisulfatos (AES)- en sedimentos superficiales del estuario del río Guadalete, localizado al norte de la Bahía de Cádiz (SO de España). Para ello se llevaron a cabo muestreos estacionales durante dos años en tres estaciones diferentes, una de ellas localizada río arriba y en las inmediaciones de la zona de descarga de una estación depuradora de aguas residuales (EDAR). También se muestreó una estación control en un caño mareal situado dentro de los límites de un parque natural cercano al estuario. El rango de concentraciones de LAS y AES encontrado estuvo comprendido entre 196 y $2864 \mathrm{ng} \mathrm{g}^{-1}$ y entre 147 y $557 \mathrm{ng} \mathrm{g}^{-1}$ respectivamente, correspondiendo los valores más bajos a la estación control y los más altos a aquella situada cerca de la descarga de la EDAR. En términos generales, se detectó un descenso en las concentraciones de ambos tensioactivos durante el verano, cuando los procesos degradativos alcanzan mayor velocidad, mientras que las concentraciones más altas correspondieron a los meses con mayores precipitaciones, cuando se registra un descenso en la temperatura y tienen lugar descargas de agua residual sin tratar a causa de la saturación de la EDAR. Debido a procesos de adsorción y degradación diferencial, la distribución relativa de homólogos de LAS en el sedimento mostró un porcentaje mayor para aquellos con mayor longitud de cadena alquílica, mientras que los homólogos de AES con número par de carbonos en dicha cadena y los etoxímeros con menor número de grupo etoxilados fueron predominantes. No se detectó ningún riesgo para los organismos acuáticos teniendo en cuenta las concentraciones encontradas en el estuario para ambos tensioactivos.

Palabras clave: tensioactivos aniónicos, sedimentos, estuarios, variaciones estacionales, aguas residuales, evaluación de riesgo ambiental. 


\section{INTRODUCTION}

Significant quantities of xenobiotics reach the receiving waters despite the fact that most of the wastewaters from European cities are now treated in wastewater treatment plants (WWTPs) prior to their discharge. Therefore, marine and estuarine ecosystems are subjected to the effects of organic compounds originating from the adjacent populations. Synthetic surfactants are included among these contaminants. They are primary cleaning agents used in laundry, cleaning and personal care products, as well as in other applications (paints, pesticides, etc). The world production of surfactants is estimated to be about 10 million tons per year (Holmberg et al., 2003), with approximately 60\% of this amount belonging to surfactants of the anionic type (negatively charged). In this paper we have focused our attention on the anionic surfactants having the largest volume of use in Europe: linear alkylbenzene sulfonates (LAS), with a production of 430000 tons per year (HERA LAS report, 2009), alkyl ethoxysulfates (AES), with a production of 276000 tons/year (HERA AES report, 2004), and alkyl sulfates (AS), with a production of 102000 tons/year (HERA AS report, 2002). These chemicals are often produced as mixtures with variable compositions in homologue and/or ethoxymer percentages. Figures $1 \mathrm{a}$ and $1 \mathrm{~b}$ show the molecular structure for linear alkylbenzene sulfonates (LAS) and alkyl ethoxysulfates (AES), respectively, with alkyl sulfates (AS) corresponding to the AES homologues without ethylene groups.

Between $95 \%$ and $99 \%$ of anionic surfactants are removed in WWTPs and the remaining amount is discharged to the environment (McAvoy et al., 1998). Therefore, in spite of their relatively fast degradation in the receiving waters (Scott and Jones, 2000; León et al., 2004), significant levels of LAS have been reported in aquatic ecosystems (González-Mazo et al., 1998; León et al., 2002; Lara-Martín et al., 2006; Hampel et al., 2009). Concentrations of this surfactant are often much lower in water (usually ranging from less than 1 to 100 $\mu \mathrm{g} \mathrm{L}^{-1}$ ) than in sediments (up to several tens of $\mathrm{mg} \mathrm{kg}^{-1}$ in the most contaminated areas), where LAS (especially those homologues having a longer alkyl chain) tend to be accumulated after sorption onto suspended solids, then remaining preserved fairly well under anaerobic conditions. Studies concerning the presence of AS and AES in waters (Popenoe et al., 1994; Pojana et al., 2004) and sediments (Lara-Martín et al., 2005; LaraMartín et al., 2006) are few in comparison with those for LAS, but they have shown a similar behaviour, with values of up to $1 \mu \mathrm{g} \mathrm{L}^{-1}$ and $2 \mathrm{mg} \mathrm{kg}^{-1}$, respectively.

Because of their high consumption and source specificity, analysis of anionic surfactants in sediments can be used to trace and locate urban contamination sources such as wastewater inputs into estuaries or bays. Moreover, variations in these inputs can also be monitored because they are reflected in changes in the environmental concentrations of these compounds. Papers dealing with the distribution and seasonal variations of LAS concentration in waters (Takada et al., 1992; González-Mazo et al., 1998; Quiroga et al., 1999) and sediments (Inaba and Amano, 1988; DelValls et al., 2002; Hampel et al., 2009) have in most cases reported the existence of lower values in summer than in winter, mainly due to slower degradation at low temperatures. This trend has been partially confirmed for AES and AS in fresh and marine waters by means of biodegradation laboratory tests (Vashon and Schwab, 1982; Guckert et al., 1996), some of them effectively showing that degradation of these compounds seems to be slower at low temperatures, as well as in non-polluted areas (Quiroga et al., 1999; George, 2002). However, no previous studies have dealt with distribution and seasonal variations of AS and AES in an aquatic environment, so further studies are required in order to achieve a better understanding of their environmental behaviour. For this purpose, several seasonal sampling campaigns were carried out along the estuary of the River Guadalete (SW Spain). The specific objectives were to determine the existence of seasonal patterns in the distribution of LAS and AES in sediments from this area, the sources and concentrations of these compounds, and the changes that may occur in their homologue and ethoxymer distributions once they reach the environment. Finally, an environmental risk assessment was carried out in order to determine whether the concentrations measured along the estuary for the two surfactants represent a hazard for aquatic organisms.

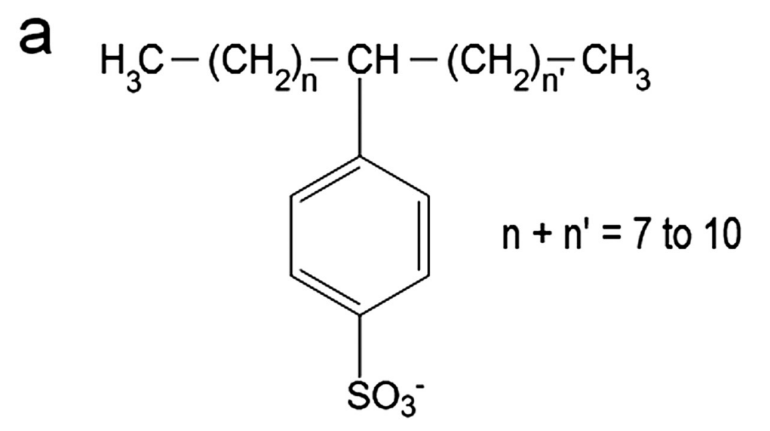

b

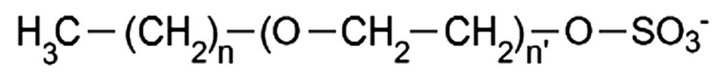

$n=11$ to 15

FIG. 1. - Chemical structures of a) linear alkylbenzene sulfonates (LAS) and b) alkyl ethoxysulfates (AES). 

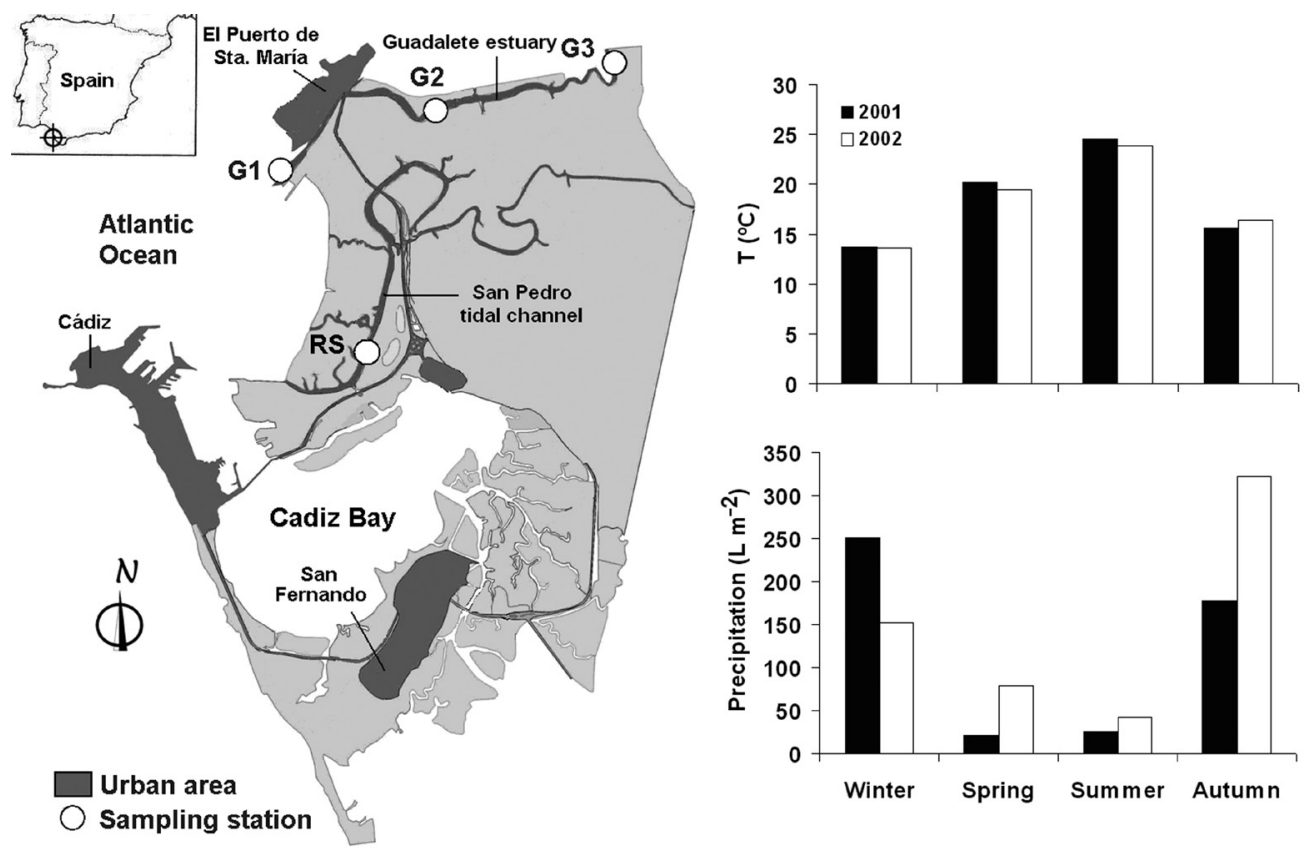

FIG. 2. - Map of the Bay of Cadiz (SW of Spain) showing its location and the positions of the sampling stations in the Guadalete estuary (G1, G2 and G3) and San Pedro tidal channel (RS). Average temperatures and seasonal precipitations during the years 2001 and 2002 in this area are also shown.

\section{MATERIALS AND METHODS}

\section{Sampling and sample pre-treatment}

The study was carried out in the final stage of an estuary (River Guadalete) in the north of the Bay of Cadiz, SW Spain (Fig. 2). Average seasonal precipitations and temperatures in the area for the years 2001 and 2002 are also represented in Figure 2 (data from the Environmental Department of the Andalusian Government). Sediment grab samples were taken in duplicate and seasonally from three stations during these two years. The first of these stations (G1) is located at the mouth of this river, where El Puerto de Santa Maria, a town of about 100000 inhabitants, is situated. Wastewaters from this population are treated and discharged into the ocean rather than the river, although occasional wastewater discharges take place through the old sewage network into the estuary. The third station (G3) is located near to the effluent discharge point of the WWTP of Jerez (a town of about 200000 inhabitants upstream). The remaining stations were station G2, placed between G1 and G3, and a control station (RS) at the tidal channel named Río San Pedro, located inside the natural park adjacent to the River Guadalete.

The stations were sampled from a pneumatic launch on an ebbing tide by means of a Van Veen grab, taking the topmost $10 \mathrm{~cm}$ layer of the sediments. The sediment samples were maintained at a temperature of $4^{\circ} \mathrm{C}$ during transfer to the laboratory, where they were frozen and stored until the time of analysis. Later, the sediments were dried at $65^{\circ} \mathrm{C}$ in a heater until constant weight. The dried samples of sediment were milled using a zirconium oxide ball mill and passed through a $0.063 \mathrm{~mm}$ sieve.

\section{Chemicals}

All solvents used were of chromatography quality and were purchased from Scharlau (Barcelona, Spain). Commercial mixtures of AES were kindly supplied by KAO Corporation (Barcelona, Spain) and the company Procter and Gamble (P\&G, Cincinnati, USA). Their proportional compositions of the various homologues were $\mathrm{C}_{12}(68.5 \%), \mathrm{C}_{14}(29.8 \%)$ and $\mathrm{C}_{16}(1.7 \%)$ for the KAO standard and $\mathrm{C}_{12}(17.5 \%), \mathrm{C}_{13}(28.2 \%)$, $\mathrm{C}_{14}(32.1 \%)$ and $\mathrm{C}_{15}(22.2 \%)$ for the $\mathrm{P} \& \mathrm{G}$ standard. Commercial LAS and a $\mathrm{C}_{16}$ LAS pure standard were supplied by Petroquímica Española S.A (PETRESA, Cadiz, Spain). The proportional composition of the different homologues for LAS is as follows: $\mathrm{C}_{10}(10.9 \%)$, $\mathrm{C}_{11}(35.3 \%), \mathrm{C}_{12}(30.4 \%), \mathrm{C}_{13}(21.2 \%)$ and $\mathrm{C}_{14}(1.1 \%)$.

\section{Analytical methodology}

The complete analytical protocol has been previously described by Lara-Martín et al. (2005). Briefly, duplicates of five grams of the collected sediments were extracted with methanol in an automated Soxhlet unit (Büchi) for 5 hours in hot Soxhlet mode. The methanolic extract was then evaporated and redissolved in 100 $\mathrm{mL}$ of water in an ultrasonic bath. These extracts were purified and preconcentrated by solid-phase extraction using minicolumns of the hydrophobic $\mathrm{C}_{18}$ type (500 $\mathrm{mg}$, Bond Elut, Varian) in an automated solid phase extraction (SPE) AutoTrace unit (Zymark) rinsed and eluted with methanol.

AS, AES and LAS were analyzed using a Spectrasystem liquid chromatograph with autosampler coupled to a LCQ ion-trap mass spectrometer (Thermo). 
The homologues were separated using a $125 \times 2 \mathrm{~mm}$ ( $3 \mu \mathrm{m}$ particle size) Luna C-18 column (Phenomenex) and water (with $5 \mathrm{mM}$ of acetic acid and triethylamine added) and acetonitrile/water (8:2, v/v) were used as solvents. Electrospray ionization (ESI) was used in the mass spectrometer, scanning the mass/charge $(\mathrm{m} / \mathrm{z})$ range between 75 and 800 in full scan negative ion mode. Identification of each LAS homologue and AES ethoxymer (including AS) was carried out by monitoring their main fragment ions and their specific fragment ion with $\mathrm{m} / \mathrm{z} 183$ and 97 , respectively. Concentrations were determined by measuring the peak areas of the main fragment ions using external standards followed by normalization by means of a $\mathrm{C}_{16}$ LAS used as internal standard. LAS and AES results were expressed as the sum of their respective homologues. In the case of AES, each homologue comprises the sum of every ethoxymer including AS, without any ethylene group.

\section{RESULTS}

Table 1 shows the variations in LAS and AES concentrations during the years 2001-2002 and 2002, respectively, at the different sampling stations along the Guadalete estuary (G1, G2 and G3) and the tidal channel named Río San Pedro (RS). LAS values ranged from 196 to $2024 \mathrm{ng} \mathrm{g}^{-1}$ in 2001 and from 238 to $2864 \mathrm{ng} \mathrm{g}^{-1}$ in 2002 , whereas AES concentrations ranged from 147 to $557 \mathrm{ng} \mathrm{g}^{-1}$ in 2002. With respect to the distribution of the different homologues for the target anionic surfactants in sediments, LAS and AES homologues with 10 to 13 and with 12 to 16 carbon atoms in their alkyl chain, respectively, were found in sediments at the sampling stations. Table 2 reports the average distribution of homologues of each surfactant in sediments and commercial mixtures. In general, those homologues having longer alkyl chains were predominant in all samples (e.g. up to $1074 \mathrm{ng} \mathrm{g}^{-1}$ for
$\mathrm{C}_{13}$ LAS and up to $427 \mathrm{ng} \mathrm{g}^{-1}$ for $\mathrm{C}_{14}$ AES). AES also had from 0 up to 12 ethoxylated units (EO), showing an average length of 1.6 (Table 2).

\section{DISCUSSION}

LAS concentrations (Table 1) were similar to those previously reported in this area (Lara-Martín et al., 2005), in the North Sea (Bester et al., 2001) and in Japanese lakes (Inaba and Amano, 1988), but significantly lower than those found in more polluted areas on the Spanish coasts that are subjected to untreated wastewater discharges (González-Mazo et al., 1998; Petrovic et al., 2000; DelValls et al., 2002). Alkyl ethoxysulfate values in sediment were from 147 to 557 $\mathrm{ng} \mathrm{g}^{-1}$ in sediment versus less than $0.5 \mu \mathrm{g} \mathrm{L}^{-1}$ in water, several orders of magnitude higher than those previously reported in river waters (Popenoe et al., 1994) and similar to concentrations found previously in marine sediments (Lara-Martín et al., 2005; Lara-Martín et al., 2006). However, due to the lack of environmental data for these compounds we are unable to draw further comparisons. As a general trend, AES concentrations in sediment were lower than those reported for LAS at the same sampling stations, which is mostly due to their lower production and usage.

An increase in longer alkyl chain homologue percentages can be observed for LAS in sediments in comparison with commercial mixtures (Table 2) due to their greater hydrophobicity and, consequently, their greater affinity for the particulate phase, as has been described previously by other authors (Rubio et al., 1996; González-Mazo et al., 1998). The results also show that AES homologues with an alkyl chain with an even number $\left(\mathrm{C}_{12}\right.$ and $\left.\mathrm{C}_{14} \mathrm{AES}\right)$ of carbon atoms are predominant over homologues with an odd number $\left(\mathrm{C}_{13}\right.$ and $\mathrm{C}_{15} \mathrm{AES}$ ), probably because in Europe most AES are produced using coconut-type alcohol polyethoxy-

TABLE 1. - Concentrations of LAS and AES homologues (ng g ${ }^{-1}$ ) during the four seasons (Winter, Spring, Summer and Autumn) of the years 2001 and 2002 in sediment samples from Guadalete estuary (G1, G2 and G3) and Río San Pedro (RS). n.s. = not sampled, n.d. = not detected

\begin{tabular}{|c|c|c|c|c|c|c|c|c|c|c|c|c|c|c|c|c|}
\hline \multirow[b]{2}{*}{2001} & \multicolumn{4}{|c|}{ G1 } & \multicolumn{4}{|c|}{$\mathrm{G} 2$} & \multicolumn{4}{|c|}{ G3 } & \multicolumn{4}{|c|}{ RS } \\
\hline & Win & Spr & Sum & Aut & Win & Spr & Sum & Aut & Win & Spr & Sum & Aut & Win & Spr & Sum & Aut \\
\hline C10-LAS & 31 & 57 & n.s. & 16 & 106 & 70 & 7 & 31 & 125 & 64 & 44 & 30 & 70 & 59 & n.s. & 28 \\
\hline C11-LAS & 117 & 149 & n.s. & 71 & 206 & 210 & 54 & 104 & 427 & 167 & 89 & 72 & 80 & 157 & n.s. & 67 \\
\hline C12-LAS & 149 & 170 & n.s. & 76 & 211 & 284 & 134 & 113 & 610 & 164 & 118 & 59 & 112 & 156 & n.s. & 55 \\
\hline C13-LAS & 234 & 260 & n.s. & 121 & 195 & 538 & 339 & 201 & 862 & 600 & 198 & 49 & 18 & 181 & n.s. & 45 \\
\hline$\Sigma$ LAS & 531 & 636 & n.s. & 284 & 719 & 1102 & 534 & 449 & 2024 & 996 & 450 & 210 & 281 & 553 & n.s. & 196 \\
\hline \multicolumn{17}{|l|}{2002} \\
\hline C10-LAS & 26 & 120 & 17 & 29 & 68 & 65 & 42 & 58 & 58 & 43 & 21 & 255 & 17 & 21 & 26 & 22 \\
\hline C11-LAS & 126 & 392 & 111 & 173 & 265 & 259 & 206 & 345 & 236 & 184 & 224 & 615 & 78 & 96 & 223 & 150 \\
\hline C12-LAS & 170 & 471 & 111 & 357 & 362 & 364 & 251 & 401 & 320 & 290 & 287 & 921 & 106 & 81 & 257 & 78 \\
\hline C13-LAS & 216 & 392 & 116 & 328 & 319 & 402 & 295 & 295 & 339 & 313 & 228 & 1074 & 37 & 53 & 332 & 91 \\
\hline$\Sigma$ LAS & 538 & 1375 & 355 & 886 & 1014 & 1091 & 794 & 1098 & 953 & 830 & 760 & 2864 & 238 & 251 & 838 & 341 \\
\hline C12-AES & 30 & 52 & 39 & 49 & 71 & 77 & 87 & 126 & 58 & 47 & 44 & 196 & 33 & 94 & 97 & 64 \\
\hline C13-AES & 52 & 110 & n.d. & n.d. & 66 & n.d. & n.d. & n.d. & n.d. & n.d. & n.d. & 105 & n.d. & n.d. & n.d. & n.d. \\
\hline C14-AES & 85 & 203 & 136 & 178 & 172 & 177 & 240 & 427 & 162 & 97 & 147 & 225 & 116 & 145 & 219 & 206 \\
\hline C16-AES & n.d. & n.d. & 2 & n.d. & 2 & 3 & 5 & 5 & n.d. & 2 & n.d. & 10 & n.d. & 3 & 9 & 2 \\
\hline$\Sigma \mathrm{AES}$ & 168 & 365 & 176 & 227 & 311 & 257 & 332 & 557 & 220 & 147 & 190 & 536 & 149 & 242 & 325 & 272 \\
\hline
\end{tabular}


TABLE 2. - Distributions of LAS homologues and AES homologues and ethoxymers in sediment samples and commercial mixtures.

\begin{tabular}{lcccc}
\hline Homologue & \multicolumn{3}{c}{ Sediment sample } & Commercial mixture \\
\hline LAS & Average (\%) & SD & PETRESA \\
C10 & 5.3 & 1.6 & 10.9 \\
C11 & 26.0 & 3.8 & 35.3 \\
C12 & 34.6 & 2.8 & 30.4 \\
C13 & 34.0 & 4.3 & 21.2 & \\
Homologue chain length & 12.0 & 0.1 & & 11.4 \\
\multicolumn{1}{l}{ AES } & Average (\%) & SD & P\&G & KAO \\
C12 & 24.5 & 6.4 & 17.5 & 68.5 \\
C13 & 9.3 & 13.3 & 28.2 & 0.0 \\
C14 & 65.5 & 12.6 & 32.1 & 29.8 \\
C15 & 0.0 & 0.0 & 22.2 & 0.0 \\
C16 & 0.8 & 0.7 & 0.0 & 1.7 \\
EO chain length & 1.6 & 0.8 & 4.2 & 3.1 \\
\hline
\end{tabular}

lates (KAO standard) instead of petrochemical ones (P\&G standard) (HERA AES report, 2004). Popenoe et al. (1994) found a similar homologue distribution pattern in waters in the United States. Similar to the case of LAS, a more hydrophobic homologue $\mathrm{C}_{14}$ is found in relatively higher proportions in sediments than the shorter and less hydrophobic homologue $\mathrm{C}_{12}$. The average number of ethoxylated units in sediments is lower than that in commercial mixtures due to the increasing hydrophobicity of shorter AES ethoxymers and, therefore, enhanced affinity for the organic carbon present in sediment. The contribution of naturally-produced sulfonated organic compounds (Schwitzguebel et al., 2001) and AS manufactured and used in other products separately from AES (HERA AS report, 2002) may also play an important role. No significant differences were found for homologue and ethoxymer distributions between the sampling stations and from one season to another.

Regarding the longitudinal distribution of LAS and AES along the estuary, Figures 3 and 4 show the total concentration of these surfactants for every sampling station during the years 2001-2002 and 2002, respectively. LAS values along the estuary (sampling stations from G1 to G3) were generally higher than those at the tidal channel (sampling station RS), which is located inside a natural park and has no urban areas nearby. Concentrations found upstream, near the discharge point of the WWTP, were generally higher than those at the mouth of the estuary. This treatment plant appeared to be the main source for anionic surfactants in the area in spite of the high removal efficiency for these compounds in WWTPs (McAvoy et al., 1998). Water samplings carried out in the same estuary lead to the same conclusions (Álvarez-Muñoz et al., 2007), as concentration of dissolved LAS increases upstream, reaching the highest levels $\left(92 \mu \mathrm{g} \mathrm{L}^{-1}\right)$ where the WWTP is located and showing a sharp decrease after that. The decrease in LAS concentration downstream, the further the station is from the effluent discharge point, can be explained due to dilution, sorption and degradation processes that take place in the aquatic environment (González-Mazo et al., 1998). A similar but smoother longitudinal distribution was observed for AES, although slightly higher values were found at sampling station G2 than at G3. An exception to this trend was observed in the sampling made in spring 2002 (Figs. 3 and 4), where the maximum concentration for both anionic surfactants was located at the mouth of the estuary (station G1). This fact could be attributed to the occasional wastewater discharges that take place through the old sewage net of the adjacent town of El Puerto de Santa Maria.

Apart from differences from one sampling station to another, changes in the concentration of anionic surfactants could also be found from one season to another (Figs. 3 and 4). Lower values were found during the summer, when the temperature is higher (Fig. 2) and degradation rates consequently increase, in agreement with previous studies conducted in laboratory tests (Quiroga et al., 1999; León et al., 2004) as well as

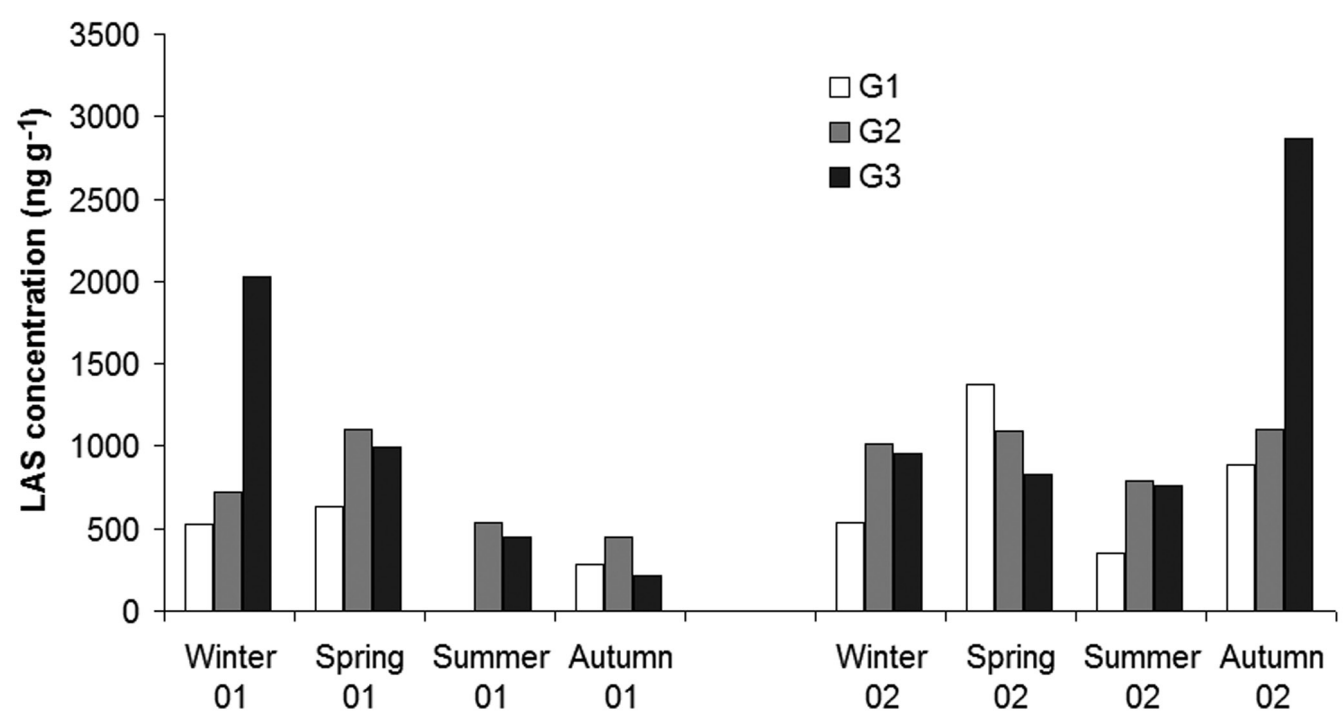

FIG. 3. - Annual variations in the LAS concentrations (expressed as ng g-1) during the years 2001 and 2002 in the Guadalete estuary (sampling stations G1, G2 and G3). 


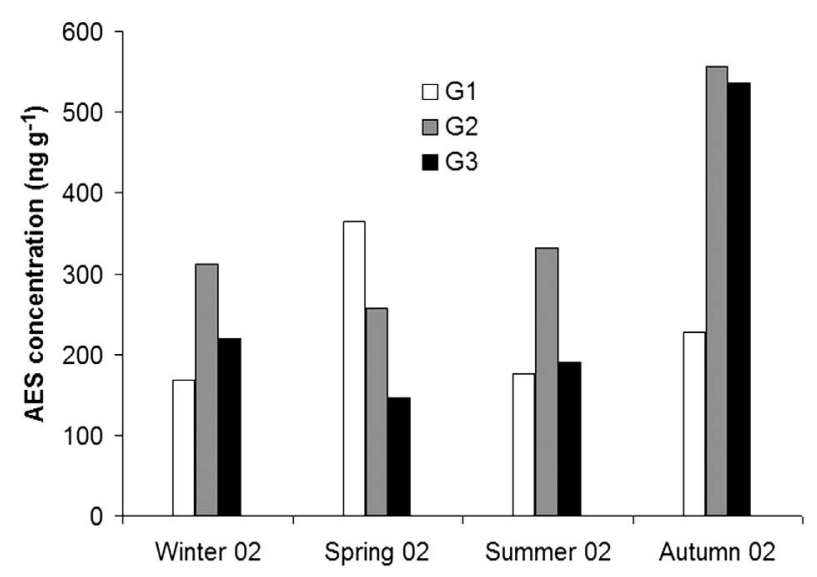

FIG. 4. - Annual variations in the AES concentrations (expressed as ng $\mathrm{g}^{-1}$ ) during the year 2002 in the Guadalete estuary (sampling stations G1, G2 and G3).

field findings (Inaba and Amano, 1988; Takada et al., 1992). However, Hampel et al. (2009) recently found an inverse trend in the Tagus estuary (Portugal), which was mainly attributed to a higher dilution of the LAS input during the winter. In our case, the highest LAS concentrations were detected in the winter of 2001 and the autumn of 2002 (Fig. 3), due not only to the lower temperatures occurring during these months but also to the high precipitations (Fig. 2), which exceeded the capacity of the WWTP of Jerez and forced it to discharge wastewater without prior treatment. A similar seasonal variation was observed for AES in 2002 (Fig. 4 ), although the differences were slighter.

Overall, the concentrations reported in this estuary are useful for carrying out an environmental risk assessment (ERA) for LAS and AES. This is based on the evaluation of the ratio between the predicted (or already measured) environmental concentrations (PECs) and the predicted no-effect concentrations (PNECs). The highest concentrations for LAS and AES in the estuary were $2864 \mathrm{ng} \mathrm{g}^{-1}$ and $557 \mathrm{ng} \mathrm{g}^{-1}$, respectively, both measured in autumn 2002, and would represent the worst-case scenario (scenario 1) when used as PECs in sediments. Using average values (891 and $291 \mathrm{ng} \mathrm{g}^{-1}$ for LAS and AES, respectively) as PECs is another approach to aim for a most realistic scenario (scenario 2). There are several ways to calculate the values of PNECs. They can be derived from previous laboratory-based toxicity tests on several organisms. For example, Hampel et al. (2007) determined PNECs for LAS in sediments by using four different species of sediment-dwelling marine organisms exposed to several LAS concentrations and measuring $\mathrm{LC}_{50}$ after $96 \mathrm{~h}$ and $\mathrm{LC}_{10}$ at the end of the experiment (concentration of a compound that causes death of $50 \%$ and $10 \%$ of the exposed organisms, respectively). In this case, PNEC values ranging from 4880 to $56050 \mathrm{ng} \mathrm{g}^{-1}$ were calculated depending on the species. Another way to determine PNECs is using the equilibrium partitioning method (EPM), which takes into account the sediment/ water partitioning coefficient of the target compound. PNEC average values between 8100 and $25830 \mathrm{ng} \mathrm{g}^{-1}$ were calculated for LAS in sediments (Hampel et al., 2007; Hampel et al., 2009; HERA LAS report, 2009), and they are in the same range for AES (Dyer et al., 2000; Sanderson et al., 2006). Taking into account the PEC and PNEC values shown above, it seems clear that the PEC/PNEC ratio is less than 1 for LAS and AES in the estuary of the River Guadalete in any of the two proposed scenarios (1 and 2), which means that no hazard for the sediment community is foreseen. This is in agreement with previous studies in other rivers and in the marine environment (Sanderson et al., 2006; Hampel et al., 2007; Hampel et al., 2009), with the exception of a few "hot spots" (usually sampling stations adjacent to untreated wastewater discharge points where LAS levels are higher than $10000 \mathrm{ng} \mathrm{g}^{-1}$ ), where the PEC/PNEC ratio was above 1 . In summary, LAS and AES concentration levels in sediments were successfully used to monitor the influence of wastewater discharges in the sampling area. Both compounds show a similar longitudinal distribution and seasonal trend, in which the higher values are reached near the WWTP discharge outlet and during the wet months. Therefore, LAS and AES appear to have a similar behaviour along the Guadalete estuary, with the treated wastewater discharges from the WWTP of Jerez de la Frontera being the main source accounting for their presence in this aquatic ecosystem. Minor contributions from the occasional wastewater discharges that take place at the town of El Puerto de Santa Maria also have some influence in explaining the longitudinal distribution of surfactants in this area. Finally, no hazard for the aquatic organisms was detected along the estuary at the concentrations measured for LAS and AES in sediments.

\section{ACKNOWLEDGEMENTS}

We express our gratitude to E. de Miguel for his technical support with the LC/MS system. We also thank PETRESA, KAO Corp. and P\&G for supplying us with the surfactant standards. This study was carried out within the CICYT R\&D Project REN20012980-C02-01 and with the help of a Spanish Ministry for Education and Science grant.

\section{REFERENCES}

Álvarez-Muñoz, D., P.A. Lara-Martín, J. Blasco, A. Gómez-Parra and E. González-Mazo. - 2007. Presence, biotransformation and effects of sulfophenyl carboxylic acids in Solea senegalensis. Environ. Int., 33: 565-570.

Bester, K., N. Theobald and H.Fr. Schröder. - 2001. Nonylphenols, nonylphenol-ethoxylates, linear alkylbenzenesulfonates (LAS) and bis (4-chlorophenyl)-sulfone in the German Bight of the North Sea. Chemosphere, 45: 817-826.

DelValls, T.A., J.M. Forja and A. Gómez-Parra. - 2002. Seasonality of contamination, toxicity, and quality values in sediments from littoral ecosystems in the Gulf of Cádiz (SW Spain). Chemosphere, 46: 1033-1043.

Dyer, S.D., D.T. Stanton, J.R. Lauth and D.S. Cherry. - 2000. 
Structure-activity relationships for acute and chronic toxicity of alcohol ether sulfates. Environ. Toxicol. Chem., 19: 608-616.

George, A. - 2002. Seasonal factor affecting surfactant biodegradation in Antarctic coastal waters: comparison of a polluted and pristine site. Mar. Environ. Res., 53: 403-415.

González-Mazo, E., J.M. Forja and A. Gómez-Parra. - 1998. Fate and distribution of linear alkylbenzene sulfonates in the littoral environment. Environ. Sci. Technol., 32: 1636-1641.

Guckert, J.B., D.D. Walker and S.E. Belanger. - 1996. Environmental chemistry for a surfactant ecotoxicology study supports rapid degradation of $\mathrm{C}_{12}$-alkyl sulfate in a continuous-flow stream mesocosm. Environ. Toxicol. Chem., 15: 262-269.

Hampel, M., E. González-Mazo, C. Vale and J. Blasco. - 2007. Derivation of predicted no effect concentrations (PNEC) for marine environmental risk assessment: application of different approaches to the model contaminant linear alkylbenzene sulphonates (LAS) in a site-specific environment. Environ. Int., 33: 486-491.

Hampel, M., J. Canário, V. Branco, C. Vale and J. Blasco. - 2009. Environmental levels of linear alkylbenzene sulfonates (LAS) in sediments from the Tagus estuary (Portugal): environmental implications. Environ. Monit. Assess., 149: 151-161.

HERA AES Environmental Risk Assessment Report. - 2004. (http://www.heraproject.com/files/1-E-04-HERA\%20AES\%20 ENV\%20\%20web\%20wd.pdf)

HERA Alkyl Sulphates Environmental Risk Assessment Report. - 2002. (http://www.heraproject.com/files/3-E-04-HERA\%20 AS\%20Env\%20web\%20wd.pdf)

HERA LAS Human and Environmental Risk Assessment Report. - 2009. (http://www.heraproject.com/files/48-F-HERA_LAS Report_(Version_4_-_June_09).pdf)

Holmberg, K., B. Jonsson, B. Kronberg and B. Lindman. - 2003. Surfactants and Polymers in Aqueous Solution, second ed. Wiley, Chichester, England.

Inaba, K. and K. Amano. - 1988. HPLC determination of linear alkylbenzenesulfonate (LAS) in aquatic environment. Season changes in LAS concentration in polluted lake water and sediment. Intern. J. Environ. Anal. Chem., 34: 203-213.

Lara-Martín, P.A., A. Gómez-Parra and E. González-Mazo. - 2005. Determination and distribution of alkyl ethoxysulfates and linear alkylbenzene sulfonates in coastal marine sediments from the Bay of Cadiz (southwest of Spain). Environ. Toxicol. Chem. 24: 2196-2202.

Lara-Martín, P.A., M. Petrovic, A. Gómez-Parra, D. Barceló and E. Gónzalez-Mazo. - 2006. Presence of surfactants and their degradation intermediates in sediment cores and grabs from the Cadiz Bay area. Environ. Pollut., 144: 483-491.

León, V.M., M. Sáez, E. González-Mazo and A. Gómez-Parra. - 2002. Occurrence and distribution of linear alkylbenzene sulfonates and sulfophenylcarboxylic acids in several Iberian littoral ecosystems. Sci. Total Environ., 288: 215-226.
León, V.M., A. Gómez-Parra and E. González-Mazo. - 2004. Biodegradation of linear alkylbenzene sulfonates and their degradation intermediates in seawater. Environ. Sci. Technol., 38: 2359-2367.

McAvoy, D.C., S.D. Dyer, N.J. Fendinger, W.S. Eckhoff, D.L. Lawrence and W.M. Begley. - 1998. Removal of alcohol ethoxylates, alkyl ethoxylate sulfates, and linear alkylbenzene sulfonates in wastewater treatment. Environ. Toxicol. Chem., 17: $1705-1711$.

Petrovic, M., A. Rodriguez Fernández-Alba, F. Borrull, R.M. Marce, E. González-Mazo and D. Barceló. - 2002. Occurrence and distribution of nonionic surfactants, their degradation products, and linear alkylbenzenesulfonates in coastal waters and sediments in Spain. Environ. Toxicol. Chem., 21: 37-46.

Pojana, G., G. Cassani and A. Marcomini. - 2004. Determination, aerobic biodegradation and environmental occurrence of aliphatic alcohol polyethoxylate sulfates (AES). Intern. J. Environ. Anal. Chem., 84: 729-738.

Popenoe, D.D., S.J. Morris, P.S. Horn and K.T. Norwood. - 1994. Determination of alkyl sulfates and alkyl ethoxysulfates in wastewater treatment plant influents and effluents and in river water using liquid chromatography/ion spray mass spectrometry. Anal. Chem., 66: 1620-1629.

Quiroga, J.M., J.A. Perales, L.L. Romero and D. Sales. - 1999. Biodegradation kinetics of surfactants in seawater. Chemosphere, 39: 1957-1969.

Rubio, J.A., E. González-Mazo and A. Gómez-Parra. - 1996. Sorption of linear alkylbenzenesulfonates (LAS) on marine sediment. Mar. Chem., 54: 171-177.

Sanderson, H., B.B. Price, S.D. Dyer, A.J. DeCarvalho, D. Robaugh, S.W. Waite, S.W. Morrall, A.M. Nielsen, M.L. Cano and K.A. Evans. - 2006. Occurrence and hazard screening of alkyl sulfates and alkyl ethoxysulfates in river sediments. Sci. Total Environ., 367: 312-323.

Schwitzguebel, J.P., S. Aubert, W. Grosse and F. Laturnus. - 2001. Sulphonated aromatic pollutants. Limits of microbial degradation and potential phytoremediation. Environ. Sci. Pollut. Res., 9: 62-72.

Scott, J.S. and M.N. Jones. - 2000. The biodegradation of surfactants in the environment. Biochim. Biophys. Acta, 1508: 235-251.

Takada, H. and N. Ogura. - 1992. Removal of linear alkylbenzenesulfonate (LAS) in the Tamagawa Estuary. Mar. Chem., 37: 257-273.

Vashon, R.D. and B.S. Schwab. - 1982. Mineralization of linear alcohol ethoxylates and linear alcohol ethoxy sulfates at trace concentrations in estuarine waters. Environ. Sci. Technol., 16: 433-436.

Received November 1, 2008. Accepted July 30, 2010.

Published online November 13, 2010. 